\title{
The Relation between CSR and Innovation. Model Approach
}

\section{Dawid Szutowskị and Piotr Ratajczak ${ }^{2}$}

\begin{abstract}
The paper attempts to fulfil the research gap concerning the mutual relation between company innovation and its corporate social responsibility practices, by determining the conditions in which the innovation/CSR relation appears and develops. The research was based on systematic literature studies performed using SALSA and backwards-snowballing methods. The data was examined with the use of the meta-synthesis approach. The authors' model explaining the studied relation was proposed. The research suggested that the impact of innovation on the CSR practices depended on the type of innovation and degree of novelty involved; while the way CSR affected innovation depended on such CSR features as: type of reaction, degree of development, and field of activity. The relation was also moderated by a series of six exogenous factors: external factors, industry, company characteristics, attitude, performance, and $R \& D$.
\end{abstract}

Keywords: innovation, corporate social responsibility, CSR.

\section{INTRODUCTION}

The growing importance of corporate social responsibility (CSR) and its impact on a company's value is perceived as a shift in a management paradigm (Porter and Kramer, 2011). Fatemi and Fooladi (2013) went further, arguing that companies, which did not take into account the needs of all stakeholders, experienced a gradual destruction of their market value. Linking the financial performances of different companies with CSR has already been introduced in the literature in the 1980s and less explicitly even earlier (Carroll, 1999). Nevertheless the relation between CSR and innovation has gained academic attention only over the last decade (Rexhepi, Kurtishi \& Bexheti, 2013). Innovation was made a key to understanding the linkage between CSR and a company's social and financial performance (Visser, 2010). Nidumolu,

1 Dawid Szutowski, Ph.D., Department of Controlling, Financial Analysis and Valuation, Poznań University of Economics and Business, al. Niepodleglosci 10,61-875 Poznan, e-mail: dawid.szutowski@ue.poznan.pl.

2 Piotr Ratajczak, Ph.D. Candidate, Department of Controlling, Financial Analysis and Valuation, Poznań University of Economics and Business, al. Niepodległosci 10,61-875 Poznan, e-mail: piotr.ratajczak@ue.poznan.pl. 
Prahalad and Rangaswami (2009) pointed out conclusively that CSR is a fundamental driver of innovation. European Commission (2006) argued that CSR may contribute to sustainability development and simultaneously increase corporate competitive potential by stimulating innovation.

Scientific evidence exists, that companies strong in CSR compliance were in most cases highly innovative. Moreover Rexhepi, Kurtishi and Bexheti (2013) argued that nowadays CSR and innovation are the foundation of business competencies. Despite the growing academic attention to the relationship, there is still a substantial lack of knowledge on the conditions in which the innovation/CSR relation appears and develops. Although the positive impact of environmental mandatory regulations on innovation was well studied and proven, the relation between CSR (embracing all its aspects - not only environmental and obligatory) and innovation was not documented (Lockett, Moon \& Wayne, 2006). Wagner (2010) indicates that from a theoretical standpoint many academics accept the existence of the relationship between CSR and innovation but empirical research is rarely available and covers only one direction, i.e. the effect of CSR on innovation. MacGregor and Fontrodona (2008) recognized the relationship as a vicious circle that eventually leads to the firm integration between CSR and innovation in the path of a company's maturity.

The theoretical approach towards the corporate social responsibility evolved for at least several decades becoming a multidimensional concept. This is one of the reasons why the link between CSR and a company's value is so ambiguous. Moreover, the evolutionary direction of the CSR concept indicates that CSR and innovation should be studied together. The relevance of the relation between CSR and innovation streams from the public sector (European Commission, 2001, 2006, 2011; Norwegian Ministry, 2009) which corresponds to the broader academic discussion about interdependencies between sustainability performance, business competitiveness and economic performance.

There are theoretical, as well as empirical, papers concerning innovation and CSR although the research indicated that there are only a few models explaining the studied relation. Therefore the present study aimed at determining the conditions in which the innovation/CSR relation appears and develops.

The research was based on a systematic literature review with the use of SALSA - Search, AppraisaL, Synthesis, Analysis (Booth, Papaioannou \& Sutton, 2012) and backwards-snowballing (Jalali \& Wohin, 2012) methods. The data was integrated using the meta-synthesis approach (Walsh \& Downe, 2005). The method's interpretative (rather than aggregating) character resulted in translating by each other the data streaming from studied publications. 
As a result of the present research, the conceptual model was proposed. It represents the mutual relation between CSR and innovation. The model covers such endogenous variables as innovation type and degree of novelty involved, and such CSR features as: type of reaction, degree of development, and field of activity. At the same time, it contains six moderating variables: external factors, industry, company characteristics, attitude, performance, and R\&D. The R\&D variable has an effect only when the impact of CSR on innovation is considered. The model is delivered in graphic form. It may constitute a conceptual framework for further empirical studies.

The paper is structured as follows: the conceptual framework is focused on innovation, CSR and their relation. The methodology section presents the methods and approaches used in the research. The results section summarises the findings and delivers the model. The paper terminates with a discussion and conclusion.

\section{LITERATURE REVIEW}

Today's companies operate in a rapidly-changing environment (Gunday, Ulusoy, Kilic \& Alpkan, 2011). Such a background forces them to constantly seek for new solutions guaranteeing gaining or maintaining a competitive advantage. In light of this, innovation is crucial and inevitable for every entity. Also nowadays companies seem to favour socially responsible solutions. According to scientific evidence social responsibility positively influences a company's performance inter alia by improving its reputation (Lou \& Bhattacharaya, 2006). Therefore it seems essential for companies to stimulate the synergic effects between the two concepts.

Nowadays, the notion of innovation refers to the process of implementing positive and new ideas into business practice (Szutowski, 2016). Innovation represents a significant component of a company's strategy as it determines the direction of the firm's evolution (Siguaw, Enz, Kimes, Verma \& Walsh, 2009). Furthermore its role in stimulating market value increase is well documented (Rubera \& Kirca, 2012). The definition of CSR was formulated as "the responsibility of enterprises for their impacts on society" with the aim of "maximising the creation of shared value for their owners/shareholders and for their other stakeholders and society at large" (European Commission, 2011, p. 6). Thus the connection between the two concepts seems to be established based on the value maximization principle.

In relation to the previous definitions of CSR (European Commission, 2001) the most important shift lies in the purpose of CSR that appears to be value maximisation achieved by the introduction of innovative products, services and business models. By and large the scientific community seems 
to reject a philanthropic or marketing attitude to CSR and follows the trend developed in recent years that CSR needs to be linked to the modification of business models and concentration on innovation (Visser, 2010). In other words, companies should implement innovative production to transform the impact of its business activities on society.

Innovation may occur in every field of business activity, which results in its strong diversity. The most common approach of classifying innovation is perhaps the one proposed in the Oslo Manual (OECD \& Eurostat, 2005). It covers four types of innovation: product, process, organisational and marketing, each of which is marked by socially responsible aspects differently. While the principal benefit of new socially responsible products seems to be increased consumer satisfaction, the main advantage of new socially responsible processes manifests through the reduced use of resources and cost cutting (Tidd, 2001). Also new organisational structures, which involve improved working conditions, are better received by the staff. The second basic classification of innovation covers the degree of novelty involved in it. Such classification consists of three categories: incremental, new to the company and radical innovation (Tidd, Bessant \& Pavitt, 2005). From the point of view of social responsibility radical innovation seems to entail most advantages as its effects spread over both the company and its surroundings.

Although the classifications of CSR tend to be strongly diversified, the tendency to highlight the importance of innovation is strongly marked in the contemporary papers. Halme and Laurila (2008) concluded that there are three types of CSR: philanthropic, integration and innovation. The philanthropic type of CSR puts the emphasis on sponsorships, charity and employee voluntarism. The integration type concentrates on conducting existing business operations more responsibly. The innovation type underlines the meaning of new business models for solving social and environmental problems. Even though on the semantic level only this type refers to innovation, philanthropic and integration CSR may both entail innovative solutions improving their efficiency. Furthermore, Visser (2010) described five stages of CSR: defensive, charitable, promotional, strategic and systemic. The presence of innovation as a driver of CSR, concerns mainly the strategic and systemic CSR stages. Company systematic dedication to social responsibility impacts strongly on innovation, for it entails regular and orderly improvements supported at the strategic level. Torugsa, O'Donohue and Hecker (2013) distinguished reactive and proactive CSR. In relation to innovation, proactive CSR constitutes the clue as it concerns improvements in company principal activity. Reactive CSR on the other hand involves minimizing negative effects, which rarely is the core activity and constitutes a necessary burden. 
On the one hand the growing importance of CSR and innovation is reflected through the growing number of reports on social, environmental and research activities. On the other hand the relation between a company's corporate social responsibility and its innovation performance seems to be the domain of academia, rather than business practice. The development of synergic effects through the conduct of CSR and innovation activities seems to be impeded by the lack of knowledge on the conditions in which the innovation/CSR relation appears and develops. That is one of the reasons why modelling the link between CSR and innovation is of vital theoretical and practical importance.

The first important research gap concerns the conditions in which the innovation/CSR relation appears and develops. It seems that in the current state of knowledge further advancements are impeded by the lack of firm conceptual elaboration on the studied relation. The second one concerns the lack of a comprehensive, conceptual model presenting the relationship between innovation and CSR. Despite fragmentary evidence, performed in different contexts and only indirectly referring to it, a firm attempt to model the relationship seems to be still missing. There is scarce conceptual and empirical evidence of the existence of the relationship. In this context it seems necessary to continue the scientific discussion on the innovation/CSR mutual relation.

\section{RESEARCH METHODS}

The present research is aimed at determining the conditions in which the innovation/CSR relation appears and develops. Moreover it attempts to model the relationship between innovation and CSR. The research relied on the systematic literature review performed using the SALSA method (Booth, Papaioannou \& Sutton, 2012). Moreover the use of a backwards-snowballing approach (Jalali \& Wohin, 2012) enabled the inclusion of breakthrough and influential works. The meta-synthesis approach (Walsh \& Downe, 2005) underpinned the synthesis and analysis of the data. The search encompassed Scopus - a comprehensive scientific database covering academic articles published in nearly 22000 journals. The search strategy was determined in a preliminary study (Szutowski \& Ratajczak, 2016). The whole procedure is presented in Figure 1 accompanied by a descriptive component. 


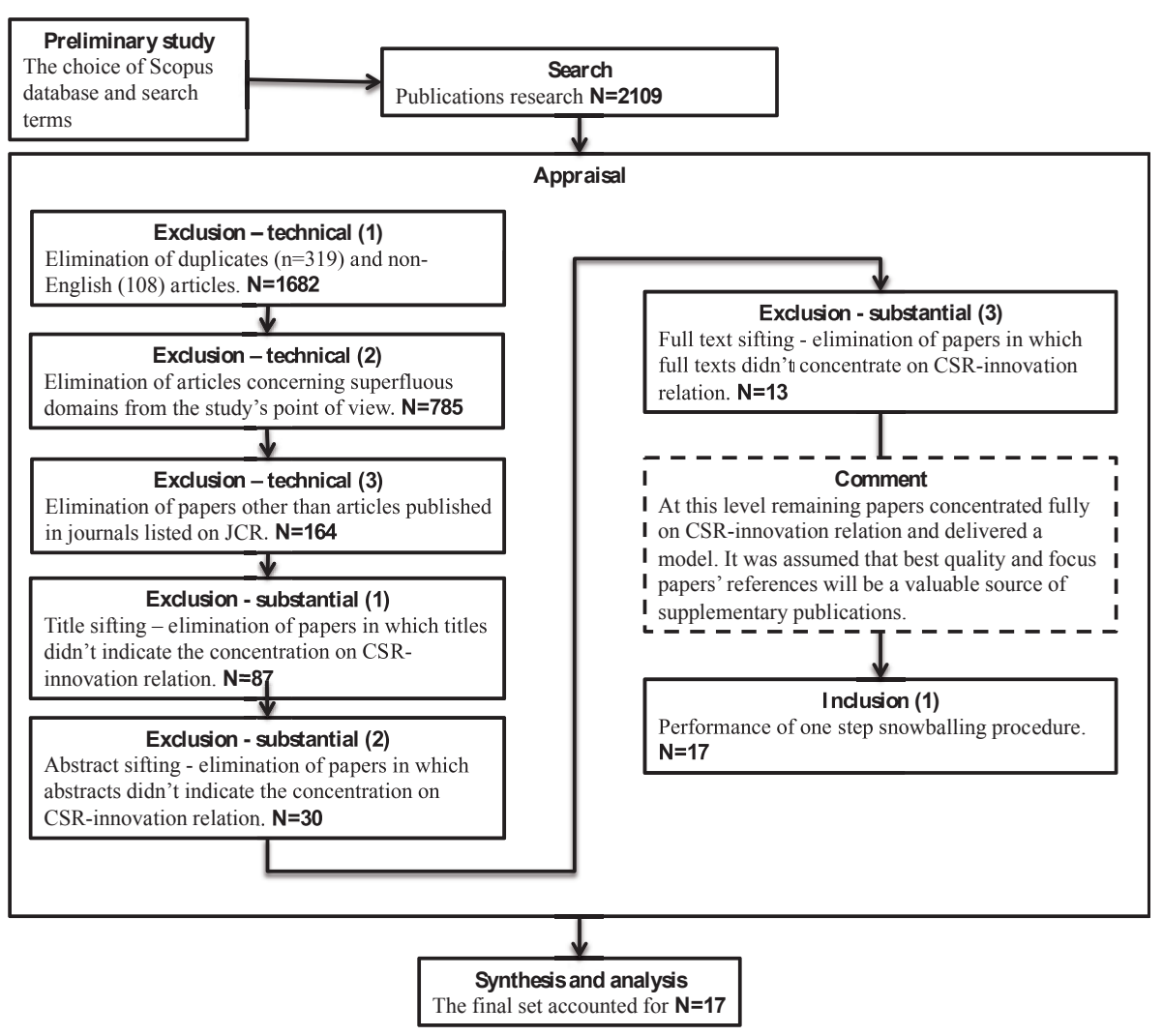

Figure 1. The strategy of literature review

The database was searched using different combinations of the following terms: innovation, novelty, improvement, social responsibility, CSR and sustain. The research was limited to papers published between January 2000 and August 2016 (inclusive) and to the subjective areas of social science, business, management and accounting, and economics, econometrics and finance. Both English and American spellings were complied. Search terms were researched in titles, keywords and abstracts. The procedure resulted in identifying 2109 papers.

The appraisal procedure was divided into two parts: exclusion and inclusion. The first part aimed at choosing the papers most suitable for research from the set. The second part aimed at supplementing the set of chosen articles by the influential works named in the reference sections.

The exclusion procedure was divided into two parts - technical and substantial. It was performed to assure the suitability of individual studies for 
the research. Firstly the duplicates and non-English papers were eliminated $(n=427)$. Secondly, all papers from the domains beyond the authors' interest were eliminated $(n=897)$. The remaining publications belonged to such domains as: business, management, accounting, economics, econometrics, finance, and general social science (eliminated ones included computer science, medicine, engineering etc.). Thirdly, only publications released in journals listed on Journal Citation Report by Thomson Reuter's were taken into consideration. At this step of the literature review 164 papers remained.

The substantial part consisted of three siftings: title sifting, abstract sifting and full text sifting. Firstly, the titles were reviewed to eliminate publications that do not concentrate on the studied relation $(n=77)$. Secondly, in-depth sifting based on the abstracts was performed eliminating unsuitable papers $(n=57)$. Thirdly, the full text of the remaining papers was studied in detail. At this step, 17 papers were eliminated, leaving 13 , which fully concentrate on the studied relation, for further analysis.

In order to fully exploit the determined set of articles, a check of references was performed using the procedure of one-step backwards snowballing (Jalali \& Wohin, 2012). It was assumed that the references of the papers will be a valuable source of supplementary publications as (1) widely accepted publications should include good quality references and (2) the 9 texts concentrated on the studied relation. The procedure allowed incorporating 4 supplementary publications described as breakthrough and influential works. Thus finally the set of analysed papers counted for 17 publications.

The last steps of the literature study relied on content analysis. The relations between innovation and CSR reported in particular papers were compared, and explained one by the other using the meta-synthesis approach (Walsh \& Downe, 2005). The data was synthesised in a table form. The breakdown into dependent and independent variables was delivered. The analysis of the research material allowed the indication of the determinants of a company's CSR-driven-innovation and innovation-driven-CSR as well creating the model explaining the relation between a company's CSR policy and its innovativeness. The last two steps in the SALSA method are described in detail in the next part of the paper.

\section{ANALYSIS}

As a result of the systematic literature review, 17 papers with models containing innovation and CSR variables were identified. However, only eleven papers delivered a clear breakdown into dependent and independent variables, and could be included in the meta-synthesis. Further investigation concentrated on these eleven papers. The data was synthesised and presented in the Table 1. 
Table 1. Models explaining the innovation/CSR relation

\begin{tabular}{|c|c|c|c|}
\hline Author (s) & $\begin{array}{l}\text { Model } \\
\text { type }\end{array}$ & Independent variables & Dependent variables \\
\hline $\begin{array}{l}\text { Husted \& Allan } \\
\text { (2007) }\end{array}$ & $\begin{array}{l}\text { Mathe- } \\
\text { matical }\end{array}$ & $\begin{array}{l}\text { NGO salience, Government salience, } \\
\text { Social responsibility orientation, Pro- } \\
\text { gressive decision-making orientation, } \\
\text { Employees number, Industry }\end{array}$ & $\begin{array}{l}\text { Social strategic posi- } \\
\text { tioning, Social strate- } \\
\text { gic planning }\end{array}$ \\
\hline $\begin{array}{l}\text { Gonzalez-Padron, } \\
\text { Hult \& Calantone } \\
\text { (2008) }\end{array}$ & $\begin{array}{l}\text { Mathe- } \\
\text { matical }\end{array}$ & Ethical climate & $\begin{array}{l}\text { Entrepreneurial inno- } \\
\text { vation }\end{array}$ \\
\hline Wagner (2010) & $\begin{array}{l}\text { Mathe- } \\
\text { matical }\end{array}$ & $\begin{array}{l}\text { Corporate social performance, R\&D, } \\
\text { Tobin's Q, Sales, Quality management } \\
\text { system }\end{array}$ & $\begin{array}{l}\text { Innovation with high } \\
\text { social benefits }\end{array}$ \\
\hline \multirow{2}{*}{$\begin{array}{l}\text { Alvarez, Lorenzo } \\
\& \text { Sanchez (2011) }\end{array}$} & \multirow{2}{*}{$\begin{array}{l}\text { Mathe- } \\
\text { matical }\end{array}$} & $\begin{array}{l}\text { CSR practices, Sector, Company's size } \\
\left.\text { and risk ( } 1^{\text {st }} \text { model }\right) ;\end{array}$ & $\begin{array}{l}\text { Innovation (1 } 1^{\text {st }} \text { mo- } \\
\text { del); }\end{array}$ \\
\hline & & $\begin{array}{l}\text { Innovation, Sector, Company's size and } \\
\text { risk ( } 2^{\text {nd }} \text { model) }\end{array}$ & $\begin{array}{l}\text { CSR practises }\left(2^{\text {nd }}\right. \\
\text { model) }\end{array}$ \\
\hline $\begin{array}{l}\text { Bocquet, Le Bas, } \\
\text { Mothe \& Pous- } \\
\text { sing (2013) }\end{array}$ & $\begin{array}{l}\text { Mathe- } \\
\text { matical }\end{array}$ & $\begin{array}{l}\text { CSR profile, Plans to adopt CSR, Or- } \\
\text { ganizational innovation, R\&D activity; } \\
\text { Employees number and education level, } \\
\text { Product length of the life cycle, Market } \\
\text { competition, Sector, Presence in the } \\
\text { group }\end{array}$ & $\begin{array}{l}\text { Product innovation, } \\
\text { Process innovation }\end{array}$ \\
\hline $\begin{array}{l}\text { McWilliams \& } \\
\text { Siegel (2000) }\end{array}$ & $\begin{array}{l}\text { Mathe- } \\
\text { matical }\end{array}$ & Financial performance & $\begin{array}{l}\text { CSR, Size, Risk, Indu- } \\
\text { stry, R\&D expenditu- } \\
\text { res, Advertising inten- } \\
\text { sity in the industry }\end{array}$ \\
\hline \multirow{3}{*}{$\begin{array}{l}\text { Kim, Brodhag \& } \\
\text { Mebratu (2014) }\end{array}$} & \multirow{3}{*}{$\begin{array}{l}\text { Mathe- } \\
\text { matical }\end{array}$} & \multirow{2}{*}{$\begin{array}{l}\text { CSR dimensions, Company's age, Em- } \\
\text { ployees number, Sales, EBITDA, Enter- } \\
\text { prise value, Stakeholder effect, Industry, } \\
\text { Region ( } 1^{\text {st }} \text { and } 2 \text { nd model); }\end{array}$} & Capex ( $1^{\text {st }}$ model $) ;$ \\
\hline & & & R\&D (2nd model); \\
\hline & & $\begin{array}{l}\text { Capex, R\&D, Company's age, Employees } \\
\text { number, Sales, EBITDA, Enterprise value, } \\
\text { Stakeholder effect, Industry, Region ( } 3^{\text {rd }} \\
\text { model) }\end{array}$ & $\operatorname{CSR}\left(3^{\text {rd }}\right.$ model $)$ \\
\hline $\begin{array}{l}\text { Miles, Munilla \& } \\
\text { Darroch (2008) }\end{array}$ & Visual & $\begin{array}{l}\text { Product, Process, Strategy, Domain and } \\
\text { business model innovation }\end{array}$ & $\begin{array}{l}\text { Social accountability, } \\
\text { Economic performan- } \\
\text { ce, Environmental } \\
\text { management }\end{array}$ \\
\hline Pana (2013) & $\begin{array}{l}\text { Descrip- } \\
\text { tive }\end{array}$ & $\begin{array}{l}\text { Planning, a study of the field, resources, } \\
\text { competencies, consultations, anticipa- } \\
\text { tion of obligatory steps, periodical eva- } \\
\text { luation, anticipation of critical points, } \\
\text { risk factor, flexible strategies, elaborated } \\
\text { models, results, forecasting outcomes, } \\
\text { planning the continuity of innovation }\end{array}$ & Social efficacy \\
\hline $\begin{array}{l}\text { Hoivik \& Shankar } \\
\text { (2011) }\end{array}$ & $\begin{array}{l}\text { Descrip- } \\
\text { tive }\end{array}$ & $\begin{array}{l}\text { Implementing CSR as a network-based } \\
\text { approach, cooperation in cluster, com- } \\
\text { petition in cluster }\end{array}$ & Innovation \\
\hline $\begin{array}{l}\text { Alvarez, Mariluz } \\
\text { \& Macias (2015) }\end{array}$ & $\begin{array}{l}\text { Descrip- } \\
\text { tive }\end{array}$ & $\begin{array}{l}\text { Flexibility, ability to adjust to unforese- } \\
\text { en circumstances, openness and com- } \\
\text { munication efficiency }\end{array}$ & CSR policies \\
\hline
\end{tabular}


Eleven studied papers delivered 14 models explaining the studied relation. All the models included both innovation or CSR dependent and independent variables. As the models were different, but interrelated, a method of data integration was necessary. In the present research the whole set of variables was integrated using the meta-synthesis approach (Walsh \& Downe, 2005). The method's interpretative (rather than aggregating) character resulted in translating the models by each other. The procedure allowed the identification of six exogenous moderators of the relation between innovation and CSR: external factors, industry, company characteristics, attitude, performance, and R\&D (which moderates only the impact of CSR on innovation). Moreover, the performed literature studies indicated that the analysis of the relation under investigation should cover not only exogenous, but also endogenous factors. Therefore it was confirmed that specific features of the innovation and CSR themselves affected the studied relation.

The meta-synthesis confirmed that the relation between innovation and CSR is mutual. Thus, both variables have an influence on each other. The procedure resulted in affirming that the relation is determined by the features of innovation and CSR themselves and moderated by a set of exogenous factors. The results of the analysis can be visualised on the graphic model - Figure 2.

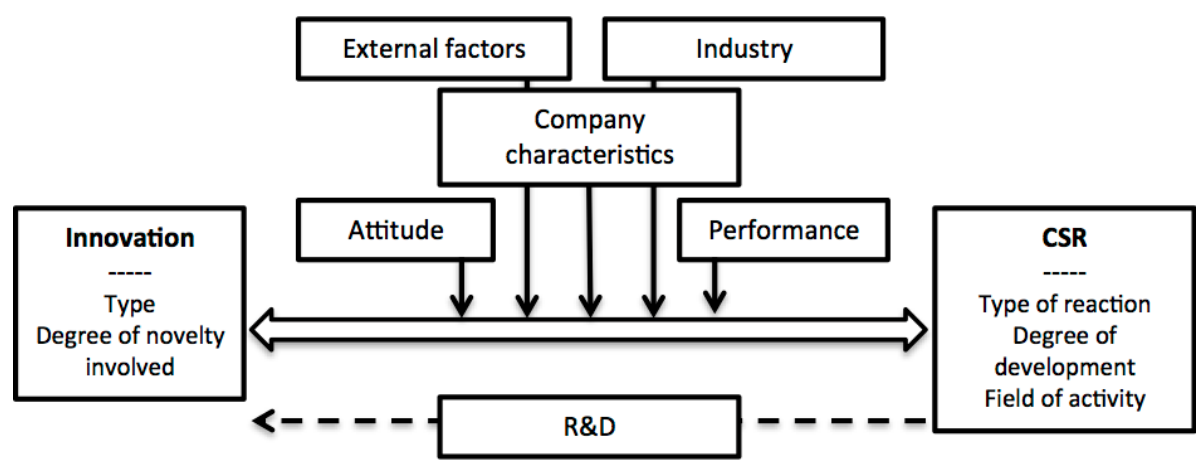

Figure 2. The model of innovation-CSR relation

The above model represents graphically the relation between innovation and CSR. It introduces the multi-typology analysis. Five exogenous factors moderate the relation in both directions, and the R\&D variable has an effect only when the impact of CSR on innovation is considered. The group of endogenous variables includes two basic features of innovation and three basic features of CSR. 
The endogenous features of innovation were represented by its type (I_T) and degree of novelty involved (I_DNI). Such division resulted from previous research (Szutowski, 2016). First, the innovation should be divided into five separate groups covering product, process, marketing, organisational and distributional innovation. Second, three groups should be extracted: radical (new to the market), new to the company, and incremental (minor improvements) innovation.

The endogenous features of CSR covered the type of reaction (CSR_R), degree of development (CSR_D), and field of activity (CSR_F). The first variable divides CSR activities into proactive and reactive. This typology reflects whether a company acts to prevent some harmful events connected with the environment or society or reacts after they happen. The second variable consists of five separate types of CSR covering defensive, philanthropic, marketing, strategic and systemic CSR (Visser, 2010). The second typology reflects a way of development that a company can go through in terms of CSR. The third variable reflects the fields of CSR activity and embraces social, environmental, ethical, human rights and consumer concerns (European Commission, 2011).

As it was stated above, the model includes such six exogenous factors: industry, company characteristics, performance, attitude, external factors, and R\&D; all of which may be operationalized in different ways. Therefore the main explanations of the consecutive variables delivered in the studied set of articles are presented below:

The industry variable (IND) stood for the industry in which a company operates.

Company characteristics (CHA) included four variables: a company's size, age and such soft qualities as ability to plan efficiently the continuity of change and ability to adjust to unforeseen circumstances.

Company performance (PER) covered three variables: EBITDA, the value of sales, and company's market value.

The attitude variable (ATT) represented either a company's attitude towards innovation, or towards CSR, depending on the direction of the relation under investigation.

External factors (EXTF) included three variables: the market competition, membership in a group of companies and competition in cluster.

$R \& D$ intensity (R\&D) was a unique variable, which affected the relation in only one direction (when the CSR affected innovation), and was represented by the company's R\&D spending divided by its sales.

The model implied that the innovation-driven-CSR and the CSR-driveninnovation depend on different endogenous variables, and slightly different exogenous factors. Despite the graphic form, innovation and CSR can be 
presented as functions of the abovementioned variables. Therefore the two functions, which represent the model, were proposed:

$$
\begin{aligned}
& I=f\left(C S R \_R, C S R \_D, C S R \_F, E X T F, I N D, C H A, A T T, \text { PER }\right) \\
& C S R=f\left(I \_T, I \_D N I, E X T F, I N D, C H A, A T T, P E R, R \& D\right)
\end{aligned}
$$

Model 1 can be empirically estimated using the following equation:

$$
\begin{array}{rl}
I_{i}=\beta_{0}+\beta_{1} C & S R_{-} R_{i}+\beta_{2} C S R_{-} D_{i}+\beta_{3} C S R_{-} F_{i}+\beta_{4} E X T F_{-} M C_{i}+\beta_{5} E X T F_{-} G_{i} \\
& +\beta_{6} E X T F_{-} C C_{i}+\beta_{7} I N D_{i}+\beta_{8} C H A_{-} S_{i}+\beta_{9} C H A_{-} A_{i}+\beta_{10} C H A_{-} P_{i} \\
& +\beta_{11} C H A_{-} U_{i}+\beta_{12} A T T_{i}+\beta_{13} P E R_{-} E B I T D A_{i}+\beta_{14} P E R_{-} S_{i}+\beta_{15} P E R_{-} M V_{i}
\end{array}
$$

Model 2 can be empirically estimated using:

$$
\begin{aligned}
C S R_{i}=\beta_{0}+ & \beta_{1} I_{-} T_{i}+\beta_{2} I_{-} D N I_{i}+\beta_{3} E X T F_{-} M C_{i}+\beta_{4} E X T F_{-} G_{i}+\beta_{5} E X T F_{-} C C_{i}+\beta_{6} I N D_{i} \\
& +\beta_{7} C H A_{-} S_{i}+\beta_{8} C H A_{-} A_{i}+\beta_{9} C H A_{-} P_{i}+\beta_{10} C H A_{-} U_{i}+\beta_{11} A T T_{i} \\
& +\beta_{12} P E R_{-} E B I T D A_{i}+\beta_{13} P E R_{-} S_{i}+\beta_{14} P E R_{-} M V_{i}+\beta_{15} R \& D_{i}
\end{aligned}
$$

Where:

I - company's innovativeness, CSR - company's CSR intensity, I_T - innovation type, I_DNI - innovation's degree of novelty, CSR_R - type of reaction, CSR_D - degree of development, CSR_F - field of activity, EXTF_MC - market competition, EXTF_G - being part of a group of companies, EXTF_CC - cluster competition, IND - industry in which company operates, CHA_S - size, CHA_A - age, CHA_P - ability to plan, CHA_U - ability to adjust, ATT - company's attitudes towards innovation or CSR, PER_EBITDA EBITDA, PER_S - company's sales, PER_MV - company's market value, R\&D - company's R\&D intensity.

In the analytical form, the model was conveyed into two functions representing innovation-driven-CSR and the CSR-driven-innovation. The operationalization of the included variables was not imposed. As the authors' model resulted from the extensive literature studies, it contains the theoretically-related variables, but can still be a subject of the scientific discussion.

\section{DISCUSSION}

The research aimed at determining the conditions in which the innovation/ CSR relation appears and develops. As a result of the meta-synthesis it was confirmed that the relation is moderated by a set of six exogenous factors: industry, company characteristics, performance, attitude, external factors and R\&D. At the same time the research indicated that the relation depends on the group of endogenous variables covering innovation and CSR features.

The mutual relation between CSR and innovation was confirmed. The assumption that CSR is an innovation driver seems to be broadly accepted 
(European Commission, 2006, 2011). Also, innovation is assumed to be the driver of CSR policy (Norwegian Ministry, 2009).

The inclusion of the industry variable in the models is a common practice, as a division on innovative and non-innovative as well as CSRintensive and CSR-non-intensive industries was often mentioned in the literature. It remains relevant because the social problems and innovative opportunities in different industries can vary widely. For the purposes of this particular research, the authors divided industries twofold, e.g. service and manufacturing companies or controversial and non-controversial industries. Furthermore Husted and Allen (2007) and Alvarez, Lorenzo and Sanchez (2011) divided industries more precisely, taking into consideration numerous different industries. The reason for such a difference results from the focus of the particular paper.

The company characteristics were represented by company size, age and such soft qualities as ability to plan efficiently the continuity of change and ability to adjust to unforeseen circumstances. The impact of company size and age on its innovativeness or CSR activities is intuitive. Yet, companies change over time in terms of many features. As far as innovation is considered, it is worth taking notice of Pavelin and Porter (2008) which proved the positive relationship between the probabilities of innovation and firm size. Company size and age are widely used in studies concerning CSR and innovation (Lopez, Perez \& Rodriguez, 2009). Although size and age of the company are the predominantly used operationalizations due to the inclusion simplicity, it seems worthy to consider different proxies as well. One of the examples is the company's risk (Alvarez, Lorenzo \& Sanchez, 2011). The ability to plan efficiently the continuity of change and the ability to adjust to unforeseen circumstances indicate that the company is able to continuously realise innovation and CSR strategies regardless of threats and inconveniences.

The performance variable was represented by the company's financial results such as EBITDA, value of sales, and the company's market value. The relationship between CSR and financial performance was the subject of numerous researches (Curran, 2005). The same variables are commonly used when investigating the relationship between innovation and financial performance (Kim, Brodhag \& Mebratu, 2014; Husted \& Allen, 2007). According to Curran (2005) the performance variable could be represented by market measures (e.g. share price, dividend rate, etc.) or accounting measures (e.g. return on equity, net income, sales growth). Günther and Hoppe (2010) showed that about half of the studies concerning CSR and financial performance used market-based measures, one-fifth accountingbased measures and a further fifth applied a mix of measures or other 
measures. The authors' model does not impose which performance variables should be used.

The attitude variable was represented either by the company's attitude towards innovation, or towards CSR. Variable inclusion was supported by literature indicating that innovation and social responsibility are mainly caused by corporate culture and management attitude (Abugre, 2014). Also, firms, which take a strategic orientation toward CSR, are more innovative (Herwina, Shamsul \& Nuryusmawati, 2013). Midttun (2009) claims that a very important role in the CSR-innovation relation is played by the company's orientation towards the burning political issues of the day, e.g. climate change, alleviation of poverty, pollution or human rights.

External factors included in the model were represented by the market competition, membership in a group of companies and competition in cluster. Literature confirming that having presence in the group influences the relation between CSR and innovation is scarce. As far as market competition is considered it is the factor fostering corporate social responsibility (Flammer, 2013). Cluster internal competition stimulates both innovativeness and R\&D intensity, for it forces companies to search for a competitive edge.

The R\&D intensity variable is presumed to moderate the one direction of the relation when CSR affects innovation. This is because R\&D intensity has a direct effect on innovation. Moreover it is often equated with innovation or treated as its proxy. The exclusion of the R\&D variable from the opposite direction of the relation where innovation affects CSR is postulated in the literature, but it seems that the definitive consensus was not reached yet (Sanzo, Alvarez, Rey \& Garcia, 2012).

The model presented in the articles consisted of variables that were identified in the literature focusing on the relation between CSR and innovation. The literature denying the inclusion of any of the variables was not identified. The set of variables included in the model remains open; the model was not intended to contain all the possible variables, but only the most significant ones.

\section{CONCLUSIONS}

The growing importance of both company innovation and company CSR practices, results from the high competition faced by entities operating in the contemporary market. Moreover, constant development, in association with taking into consideration the needs of all stakeholders, seems an absolute necessity. However, the interdependence between innovation and CSR still constitutes an important research gap. Therefore the purpose of the present research was to determine the conditions in which the innovation/CSR 
relation appears and develops. The research relied on systematic literature studies and the meta-synthesis approach.

First, the procedure allowed the identification of six exogenous factors moderating the mutual relation: external factors, industry, company characteristics, attitude, performance, and R\&D intensity (the latter only moderates the impact of CSR on innovation). Second, two main features of innovation determining their effects on CSR were indicated: type and degree of novelty involved. Third, three features of CSR important in the light of its impact on innovation were pinpointed: type of reaction, degree of development, and field of activity. Finally, the relation was presented in the graphic and functional models with a descriptive component.

The purpose of the research was achieved to a large extent. However, the study was not free of limitations. The main limitation was that the research did not indicate how to customize the variables' operationalization in order to achieve the highest informative value. The technical limitation concerned the article selection, which confined the set to the papers written in English. Moreover, the model was built on the evidence from empirical researches. However, its final form was not tested empirically. Therefore the model constitutes a starting point for in-depth studies. Further research should concentrate on the models' verification in the business environment.

\section{References}

Abugre, J. (2014). Managerial role in organizational CSR: Empirical lessons from Ghana. Corporate Governance, 14(1), 104-119.

Alvarez, I., Lorenzo, J., \& Sanchez, I. (2011). Corporate social responsibility and innovation: a resource-based theory. Management Decision, 10(10), 1709-1727.

Bocquet, R., Le Bas, C., Mothe, C., \& Poussing, N. (2013). Are firms with different CSR profiles equally innovative? Empirical analysis with survey data. European Management Jorunal, 31, 642-654.

Booth, A., Papaioannou, D., \& Sutton, A. (2012). Systematic Approaches to a Successful Literature Review, London: Sage.

Carroll, A. (1999). Corporate social responsibility. Evolution of a definitional construct. Business \& Society, 38(3), 268-295.

Curran, M. (2005). Assessing the Rate of Return of the Adoption of Corporate Social Responsibility Initiatives (PhD thesis). University of Edinburgh, Edinburgh, Scotland.

Drucker, P. (1968). The Practice Of Management. London: Harper Collins.

European Commission. (2001). Green Paper. Promoting a European Framework for Corporate Social Responsibility. Brussels, Belgium.

European Commission. (2006). Green Paper. A European Strategy for Sustainable, Competitive and Secure Energy. Brussels, Belgium. 
European Commission. (2011). A Renewed EU Strategy 2011-14 for Corporate Social Responsibility. Brussels, Belgium.

Fattemi, A., \& Fooladi, I. (2013). Sustainable finance a new paradigm. Global Finance Journal, 24, 101-113.

Flammer, C. (2013). Does product market competition foster corporate social responsibility? Evidence from trade liberalization. Strategic Management Journal, 36(10), 1469-1485.

Gonzalez-Padron, T., Hult, T., \& Calantone, R. (2008). Exploiting innovative opportunities in global purchasing: an assessment of ethical climate and relationship performance. Industrial Marketing Management, 37, 69-82.

Gunday, G., Ulusoy, G., Kilic, K., \& Alpkan, L. (2011). Effects of innovation types on firm performance. International Journal of Production Economics, 133(2), 662-676.

Günther, E., \& Hoppe, H. (2010). The relation between corporate economic and corporate environmental performance. Dresdner Beiträge zur Lehre der Betrieblichen Umweltökonomie, 41, 1-50.

Halme, M., \& Laurila, J. (2009). Philanthropy, integration or innovation? Exploring the financial and societal outcomes of different types of corporate responsibility. Journal of Business Ethics, 84, 325-339.

Herwina, R., Shamsul, B., \& Nuryusmawati, M. (2013). Attitudes towards corporate social responsibility among budding business leaders. Procedia - Social and Behavioural Sciences, 107, 52-58.

Husted, B., \& Allen, D. (2007). Strategic corporate social responsibility and value creation among large firms. Lessons from the Spanish experience. Long Range Planning, 40, 594-610.

Jalali, S., \& Wohlin, C. (2012). Systematic literature studies: Database searches vs. backward snowballing. In P. Runeson (Ed.), Empirical software engineering and measurement. Conference proceedings of the ACMIEEE (pp. 29-38). New York, USA.

Johnston, R. (1966). Technical progress and innovation. Oxford Economic Papers, 18(2), 158-176.

Kim, Y., Brodhag, C., \& Mebratu, D. (2014). Corporate social responsibility driven innovation. The European Journal of Social Science Research, 27(2), 175-196.

Lockett, A., Moon, J., \& Wayne, V. (2006). Corporate social responsibility in management research: focus, nature, salience and sources of influence. Journal of Management Studies, 43, 114-136.

Lopez, M., Perez, M., \& Rodriguez, L. (2009). Corporate social responsibility and innovation in European companies. An empirical research. Corporate Ownership and Control, 7(1), 274-284.

MacGregor, S., \& Fontrodona, J. (2008). Exploring the fit between CSR and innovation. Working Paper IESE Business School, 759, 1-23.

McWilliams, A., \& Siegel., D. (2000). Corporate social responsibility and financial performance: Correlation or misspecification? Strategic Management Journal, 21, 603-609. 
Midttun, A. (2009). Strategic CSR Innovation. Serving Societal and Individual Needs. Oslo, Norway: Norwegian School of Management.

Miles, M., Munila, L., \& Darroch, J. (2009). Sustainable corporate entrepreneurship. International Enterprise Management Journal, 5, 6576.

Myers, S., \& Marquis, D. (1969). Successful Industrial Innovation. Washington, USA: National Science Foundation.

Nidumolu, R., Prahalad, C., \& Rangaswami, M. (2009). Why sustainability is now the key driver of innovation. Harvard Business Review. Retrieved from https://hbr.org/2009/09/why-sustainability-is-now-the-key-driverof-innovation

Norwegian Ministry of Foreign Affairs. (2009). Corporate social responsibility in a global economy. Retrieved from https://www.regjeringen.no/en/ dokumenter/csrreport_short/id582764/

OECD \& Eurostat. (2005). Oslo Manual: Guidelines for Collecting and Interpreting Innovation Data (3rd ed.). Paris, France: OECD Publishing.

Pavelin, S., \& Porter, L. (2008). The Corporate social performance content of innovation in the U.K. Journal of Business Ethics, 80(4), 711-725.

Porter, M., \& Kramer, M. (2011). Creating shared value. Harvard Business Review. Retrieved from https://hbr.org/2011/01/the-big-idea-creatingshared-value

Szutowski, D., Ratajczak, P. (2016). Exploring the relationship between CSR and innovation. Sustainability, Accounting, Management and Policy Journal, 7(2), 295-318.

Rexhepi, G., Kurtishi, S., \& Bexheti, G. (2013). Corporate social responsibility (CSR) and innovation the drivers of business growth? Procedia - Social and Behavioral Sciences, 75, 532-541.

Rubera, G., \& Kirca, A. (2012). Firm innovativeness and its performance outcomes: a meta-analytic review and theoretical integration. Journal of Marketing, 76(May), 130-147.

Sanzo, M., Alvarez, L., Rey, M., \& Garcia, N. (2012). Perceptions of top management commitment to innovation and R\&D-marketing relationship effectiveness: Do they affect CSR?. Annals of Public and Cooperative Economics, 83(3), 383-405.

Schumpeter, J. (1939). Business Cycles a Theoretical, Historical, and Statistical Analysis of the Capitalist Process. New York, USA: McGraw-Hill Book Company.

Siguaw, J., Enz, C., Kimes, S., Verma, R., \& Walsh, K. (2009). Cases in innovative practices in hospitality and related services. Cornell Hospitality Report, 9(17), 6-26.

Tidd, J., Bessant, J., \& Pavitt, K. (2005). Managing Innovation. Integrating Technological, Market and Organizational Change. Chichester, UK: Wiley \& Sons.

Torugsa, N., O'Donohue, W., \& Hecker, R. (2013). Proactive CSR an empirical analysis of the role of its economic, social and environmental dimensions 
on the association between capabilities and performance. Journal of Business Ethics, 115, 383-402.

Visser, W. (2010). The age of responsibility CSR 2.0 and the new DNA of business. Journal of Business Systems, Governance and Ethics, 5(3), 7-22. Wagner, M. (2010). Corporate social performance and innovation with high social benefits: A quantitative analysis. Journal of Business Ethics, 94, 581-594.

Walsh, D., \& Downe, S. (2005). Meta-synthesis method for qualitative research: a literature review. Journal of Advanced Nursing, 50(2), 204211.

Tidd, J. (2001). Innovation management in context: environment, organisation, and performance. International Journal of Management Reviews, 3(3), 169-183.

Pana, L. (2013). Social efficacy by responsible change management. Systemic Practice and Action Research, 26, 579-588.

Szutowski, D. (2016). Innovation and Market Value: The Case of Tourism Enterprises. Warsaw, Poland: Difin.

Hoivik, H., \& Shankar, D. (2011). How can SMEs in a cluster respond to global demands for corporate responsibility?. Journal of Business Ethics, 101, 175-195.

Alvarez, J., Mariluz, M., \& Macias, M. (2015). Innovation and creativity as drivers of development and CSR. A case study of companies in Guayaquil (Ecuador). España, Revista de Economía Pública, Socialy Cooperativa, 85, $1-22$.

\begin{abstract}
Polish)
$W$ artykule podjęto próbę wypełnienia luki badawczej dotyczq̨cej wzajemnych powiqzań pomiędzy innowacjami a społecznq odpowiedzialnościq przedsiębiorstw, w szczególności w zakresie warunków, w jakich ta zależność zachodzi. $W$ badaniu posłużono się systematycznym przegladem literatury zgodnie z metodq SALSA. Syntezę i analizę publikacji przeprowadzono przy wykorzystaniu meta-syntezy. W rezultacie opracowano autorski model przedmiotowej zależności. Wskazano, że wpływ innowacji na społecznq odpowiedzialność biznesu zależy od typu i stopnia nowatorstwa innowacji, podczas gdy wpływ społecznej odpowiedzialności biznesu na innowacje zależy od typu reakcji, stopnia zaawansowania i obszaru podejmowanych działań społecznie odpowiedzialnych. Ustalono również, że zależność pomiędzy innowacjami a społecznq odpowiedzialnościq przedsiębiorstw moderowana jest przez czynniki zewnętrzne, branżę, cechy przedsiębiorstwa, motywy działania, efektywność operacyjna oraz skalę działalności badawczo-rozwojowej.
\end{abstract}

Słowa kluczowe: innowacja, społeczna odpowiedzialność biznesu, CSR. 


\section{Biographical notes}

Dawid Szutowski, Ph.D. in the Department of Controlling, Financial Analysis and Valuation at Poznań University of Economics and Business, supported by the Educational Enterprise Foundation under the program of Academic Doctoral Scholarships of the Polish National Bank Foundation.

Piotr Ratajczak, Ph.D. Candidate in the Department of Controlling, Financial Analysis and Valuation at Poznań University of Economics and Business, winner of the Best PUEB Graduates Award and Best PhD Candidates Rector's Scholarship, expert and advisor in enterprise valuation, financial modelling and corporate social performance. 